\title{
HOW BUSINESS SCHOOL PROFESSORS CAN ASSIST IN REDUCING TODAY'S LACK OF ETHICS IN BUSINESS
}

\begin{abstract}
This paper discusses how business school professors can assist in reducing today's lack of ethics in business by orienting future leaders on how to behave and decide properly when confronted with the myriad ethical dilemmas of the corporate world. To accomplish this, business school professors must be able to make future leaders understand what is right and what is wrong from the ethical point of view. This requires that they engage these future leaders in philosophical discussions on ethics in business, particularly to deconstruct the misconceptions that justify today's unethical behavior. To help them in these discussions this paper presents three explanations for today's unethical behavior, the most important misconceptions built on five half-truths, the fundamental ethical principles, and the requisites of skilled ethical reasoning.
\end{abstract}

Keywords: Ethics in Business. Misconceptions that Justify Today's Unethical Behavior. Critical Ethical Reasoning..

\section{COMO PROFESSORES DE ESCOLAS DE ADMINISTRAÇÃO PODEM AJUDAR A REDUZIR A ATUAL FALTA DE ÉTICA NOS NEGÓCIOS}

\section{RESUMO}

Este artigo discute como professores de escolas de administração podem ajudar a reduzir a atual falta de ética nos negócios orientando futuros líderes como se comportar e decidir apropriadamente quando confrontados com a miríade de dilemas éticos do mundo corporativo. Para realizar isso, os professores de escolas de administração precisam fazer os futuros líderes compreender o que está certo e o que está errado do ponto de vista ético. Isto requer que eles engajem os futuros líderes em discussões filosóficas sobre ética nos negócios, particularmente para desconstruir os equívocos que justificam a atual comportamento antiético. Para ajuda-los nestas discussões este artigo apresenta três explicações para o atual comportamento antiético, os mais importantes equívocos construídos através de cinco meias verdades, os fundamentos dos princípios éticos, e os requisitos para um proficiente raciocínio ético.

Palavras-chave: Ética nos Negócios. Equívocos que Justificam o Atual Comportamento Antiético. Raciocínio Ético Crítico. 


\section{COMO PROFESSORES DE ESCUELAS DE ADMINISTRACIÓN PUEDEN AYUDAR A REDUCIR LA} ACTUAL FALTA DE ÉTICA EN NEGOCIOS

\section{RESUMEN}

Este artículo discute cómo los profesores de las escuelas de la administración pueden ayudar a reducir la carencia actual de ética en negocio guiando futuros líderes cómo comportarse y decidir apropiadamente ante la miríada de dilemas éticos del mundo corporativo. Para lograr esto, los profesores de las escuelas de administración necesitan hacer que los futuros líderes entiendan lo que es correcto y lo que está mal desde un punto de vista ético. Esto requiere que involucren a futuros líderes en discusiones filosóficas sobre ética en los negocios, particularmente para deconstruir los conceptos erróneos que justifican el comportamiento no ético actual. Para ayudarles en estas discusiones este artículo presenta tres explicaciones para el comportamiento antiético actual, los conceptos erróneos más importantes construidos a través de cinco medias verdades, los fundamentos de principios éticos, y los requisitos para un competente razonamiento ético.

Palabras clave: Ética em Negocios. Conceptos Erróneos que Justifican el Comportamiento Antiético Actual. Razonamiento Ético Crítico.

${ }^{1} \mathrm{PhD}$ from ISM (International School of Management) Paris, Professor of Entrepreneurship, Innovation, Business Strategy, and Leadership. E-mail: rjdegen@gmail.com 


\section{INTRODUCTION}

There are three interesting explanations for today's unethical behavior in business. One explanation is given by Locke and Spender (2011) who attribute the lack of business ethics to a phenomenon they called managerialism associated with a specific group of managers that stand apart from society and see business as opportunities to plunder, whatever the consequences. The authors claim that American business schools are responsible for reinforcing the managerialism that is causing pernicious harm to business ethics.

Another explanation is presented by Mintzberg, Simons, and Basu (2002). The authors point out that the growing glorification of self-interest (a trend they called the syndrome of selfishness) built on a series of half-truths that justify today's unethical behavior has taken hold of corporations and society. The unethical behavior implicit in these half-truths will be highlighted to supplement the philosophical discussion on ethics by professors with future corporate leaders. To support these discussions, Paul and Elder (2003, 2008) explain how to use and induce future corporate leaders to use ethical reasoning and the fundamental principles of ethics to behave and decide properly when confronted with an ethical dilemma.

Not less important is the explanation given by Niles and Harris-Bowlsbey (2013). They highlight that in the U. S. industrial society occupation is one of the principal determinants of social status. Consequently, students believe that an academic degree is the best opportunity for ascension to higher salaries and social status and at the same time distance them from low prestige and low pay manual work. Because of this class perception, some future corporate leaders cheat in their student years to get the necessary academic distinction to have the edge over others in the admission to prestigious business schools and the recruiting process to the best jobs with the highest salaries (preferably from investment banks and strategy consultants). It is the end justifying the means.

The ways that business school professors (professors) influence future corporate leaders to reduce today's lack of business ethics are presented as well as the major challenges they must overcome, as many of the young students and high potential future corporate leaders cheated in their school years and that cheating no longer carries the stigma that it used to (The International Center for Academic Integrity, 2013).

\section{TODAY'S LACK OF BUSINESS ETHICS}

Locke and Spender (2011) explain that during the transformation of American organizational culture in the late nineteenth century a phenomenon appeared they called managerialism, which is associated with a specific group of managers (or caste) that share specific attributes. These attributes, according to the authors, do not reflect the culture of democratic capitalism with its commitment to collaboration; rather, this caste of managers desire to stand apart from society, to become less social and more predatory; to see both markets and business as opportunities to plunder, whatever the consequences; to take unforgiving advantage of errors, misfortunes, and circumstances of others, no matter how they arose.

The authors conclude that managerialism has done great harm to America, which is reflected in the disappearance after 1980 of America's plenty, evident in the growing gap between rich and poor and in the diminishing of its global power. They also blame managerialism for the failure by the U.S. automobile industry to meet the organizational challenges of the industry and avoid bankruptcy, and the ideology of greed for the disruption of the financial system that brought it to the edge of ruin in the early twenty-first century.

The more pernicious harm to America, according to Locke and Spender, is in the role business schools have played in reinforcing managerialism. It was the business schools, they write, that gave the caste of managers associated with managerialism a sense of themselves and the legitimacy to their predatory instincts done in the name of good management.

The influence of American business schools in the disruption of the financial system by greed and neoliberal selfishness can be attributed to their social transformation and the unfulfilled promise of management as a profession, as described by Khurana (2007). He noted that between 1965 and 1985 the number of students graduating at Harvard Business School entering financial services and consulting rose from $23 \%$ to $52 \%$. The same shift happened in other elite schools.

Khurana (2007) attributes the rush into finance by business school students to greed (because of the high salaries), to neoliberal selfishness (justified by Milton Friedman's economic theory), and to a general decline in social responsibility in corporate boardrooms, the U.S. Congress, and the business schools. He noted that by 2005 , among the 180 principals and managing directors of the 20 largest investment firms, 73 held MBAs from six elite schools (Harvard 51, Chicago 7, Columbia 6, Stanford 5, Dartmouth's Tuck 3, and Northwestern 1).

Mintzberg, Simons, and Basu (2002) explain that the growing glorification of self-interest in North America is denying much of the social progress made since the $1930 \mathrm{~s}$, and that society is reverting to an earlier and darker age. They wrote, "Greed has been raised to some sort of high calling; corporations have been urged to ignore broader social responsibilities in favor of narrow shareholder value; chief executives 
have been regarded as if they alone create the economic performance. Meanwhile, concern for the disadvantaged - simple, old-fashioned generosity - has somehow been lost" (p. 67). The authors called this trend the syndrome of selfishness built on a series of half-truths that have taken hold of corporations and society that must be challenged to reestablish the balance between self-interest and social generosity.

The balance is necessary because, according to the authors, "Prosperity is not just economic and cannot be measured by averages alone. It has to be societal too, and that depends on the distribution. Real prosperity combines economic development with social generosity" (p. 73).

\section{MISCONCEPTIONS THAT PROMOTED MANAGERIALISM AND THE SYNDROME OF SELFISHNESS}

Professors to make future leaders understand what is right and what is wrong from the ethical point of view must understand and be able to challenge the misconceptions that promoted managerialism and the syndrome of selfishness. The most important misconceptions were built on five half-truths, described by Mintzberg, Simons, and Basu (2002): economic man; maximization of shareholder value; heroic leadership; the belief that effective organizations are lean and mean, and the idea that rising prosperity benefits everyone. The origins of these half-truths are described below.

The economic man stands for the obsession men have with their self-interest and intent to maximize their gains

Mintzberg, Simons, and Basu (2002) named the obsession with self-interest the syndrome of selfishness and explain that this obsession was greatly reinforced by the model of the economic man developed by Jensen and Meckling (1994) and labeled the Resourceful, Evaluative, Maximizing Model (REMM). This model of the economic man influenced generations of MBA students.

The REMM model postulates that individuals are resourceful, evaluators, and maximizers, constantly making trade-offs and substitutions among wants specifically among the amount of each. They respond creatively to the opportunities the environment presents to them, and they work to loosen constraints that prevent them from doing what they wish to do. This interpretation of the obsession of individuals with selfinterest (particularly the work to loosen constraints that prevent them from doing what they wish to do) is praised in business schools as entrepreneurship and credited for the economic prosperity of the USA.

Jensen and Meckling (1994) explained the negative side of the obsession with self-interest when individuals have no strong ethical constraints: "Like it or not, individuals are willing to sacrifice a little of almost anything we care to name, even reputation or morality, for a sufficiently large quantity of other desired things; and these things do not have to be money or even material goods" (p. 9).

Ayn Rand (1970), in her influential writing, also contributed to reinforcing the selfish behavior by praising selfishness as a virtue (Rand \& Branden, 1970). She portrayed selfishness and individualism as the courage of the individual to confront the faceless, mindless system, to pursue beliefs as a need at the expense of measurable gain if necessary.

Simpson (2009) claimed that economic inequality in the context of a society based on voluntary trade is not only economically superior to imposing economic equality, but it is morally superior. He writes, "Attempting to reduce the levels of inequality in a society based on voluntary trade, such as by-passing laws that redistribute income, will lead to a lower productive capability and standard of living. It also contradicts the egoistic moral theory (viz., rational egoism) on which human life depends. Finally, an important implication of this paper is that government policies that seek to redistribute income should be opposed for economic and ethical reasons, while policies that seek to protect the rights of individuals to keep the wealth and income they have earned should be supported economically and ethically" (p. 536-537).

Both Rand and Simpson are, of course, railing against the socialist tendencies of absolute equality in dominant bureaucracies that existed in Eastern Europe before the fall of the Berlin Wall in 1989. Unfortunately, their arguments against absolute equality are used today to praise selfishness and justify the growing inequality in the U.S.

\section{Maximizing shareholders value is the sole objective of the corporation}

The Business Roundtable (2012) an association of chief executive officers of leading U.S. companies with over $\$ 6$ trillion in annual revenues, more than 14 million employees, and nearly a third of the total value of the U.S. stock market make the point that maximizing shareholders' value is the sole objective of the corporation: "It is the responsibility of management, under the oversight of the board, to operate the corporation in an effective and ethical manner to produce long-term value for shareholders" (p. 3). This statement reflects the free market ideas of Milton Friedman (Friedman \& Friedman, 2002) that corporations should focus on the economics of their business and leave government to take care of the social aspects.

Mintzberg, Simons, and Basu (2002) point out that the separation of the economic and social consequences of decision making (defended by economists like Milton Friedman) has a fatal flaw: 
"Every economist readily recognizes that social decisions have economic consequences, in that they cost resources. So how can any economist or business executive fail to recognize that economic decisions have social consequences, in that they directly impact human beings?" (p. 69)

Another problem raised by Mintzberg, Simons, and Basu (2002) is how shareholders today own shares in corporations. They explain: "In the modern economy, with instantaneous information, global access to capital, and internet-based stock trading, fewer and fewer shareholders are in any way committed to the business they own. Giant mutual funds buy and sell millions of shares each day to mirror impersonal market indices. Alongside these are the day traders who buy and sell within hours, looking for arbitrage or momentum opportunities" (p. 70)

These shareholders are responsible for the volatility of the stock market that scares corporate management may not be interested in the future of the corporation, in its products or customers. On the other hand, these shareholders create pressure on corporate management not to miss the quarter estimates and so not upset the expectations of the market analysts.

This exclusive focus of shareholders on short-term financial performance tends to make them unaware of or even disinterested in the means by which the results were obtained and so give the CEOs almost absolute power over the organization. Not surprisingly, some CEOs use this excessive power to promote their selfinterest by giving themselves large bonuses and benefits, even when the financial performance of the corporation does not justify it.

\section{Corporations require heroic leaders}

The myth of the heroic leader was indirectly promoted by shareholders that, following the agency theory developed by Jensen and Meckling (1976), aligned their interests with the interests of the CEOs by giving them generous bonuses for financial performance. The assumption made by the shareholders was that CEOs are solely responsible for corporate performance.

Mintzberg, Simons, and Basu (2002) explain that by simply co-opting CEOs with disproportionally large rewards for financial performance, shareholders were able to appropriate much of the financial benefit generated by the corporations. According to them (citing the Executive Excess 2001 survey) in the 1990 s, CEOs' pay rose by $570 \%$, profits by $114 \%$, and average worker pay rose by $37 \%$, barely ahead of inflation for the period that was $32 \%$. These performances in the 1990 s created the myth picked up by the all-too-willing media (hungry for personalities and simple explanations) of the heroic CEOs that single-handedly were responsible for the good performance of their corporations.
Ghoshal (2005) points out that based on extensive research, the agency theory (which underlies the entire intellectual edifice in support of shareholder value maximization) has little explanatory or predictive power of corporate financial performance. In other words, large rewards paid to CEOs do not explain or predict the financial performance of the corporations under their responsibility.

Rosenzweig (2007) attributes the myth of the heroic CEOs to what he called the halo effect or the tendency to make inferences about the performance of CEOs on the basis of a general impression of the performance of the corporations they manage. This occurs because it is difficult for most people to measure the separate influences on corporate performance independently; there's a common tendency to blend them in the person of the CEO. This means that when a corporation performs well financially for reasons that could have no relationship with the leadership of the CEOs, they are nevertheless praised as heroes, and if the financial results are disappointing they are labeled as villains.

Mintzberg, Simons, and Basu (20020 criticize this heroic personality created by the media and shareholders. They point out that no individual can deliver such an inflated expectation, and that real leadership is often more quiet than heroic. Collins (2001) confirmed this with his research. He wrote, "We were surprised, shocked really, to discover the type of leadership required for turning a good company into a great one. Compared to high profile leaders with big personalities who make headlines and become celebrities, the good-to-great leaders have come from Mars. Self-effacing, quiet, reserved, even shy - these leaders are a paradoxical blend of personal humility and professional will. They are more like Lincoln and Socrates than Patton or Caesar" (p. 14-15)

Mintzberg, Simons, and Basu (2002) explain that many CEOs intending to conform to the heroic images created and expected to by the media and shareholders, announce magnificent strategies, do dramatic deals, and promise grand results. They point out that these heroic CEOs, as they gamble with shareholders' money, are protected no matter what happens. They cash in their rewards if the stock goes up and bail out with golden parachutes if it goes down sometimes even both.

This system promotes moral hazard by the CEOs by allowing them to make large bets for shortterm rewards and leave with the rewards when these bets don't produce the expected results. It is interesting that large institutional shareholders may even encourage CEOs to take risky bets to give a short-term boost to share prices and allow them to cash in substantial profits by selling their stake in the corporation. They may even buy back the stocks after the unsuspecting buyers of their shares take the loss to restart the game with a new CEO. The losers, when risky bets by CEOs don't produce the expected results 
and may even ruin the corporation, are employees, customers, unsuspecting new shareholders, and the economy - as was seen in the financial crisis of 2007 (Degen, 2009).

\section{Effective organizations are lean and mean}

Mintzberg, Simons, and Basu (2002) explain that lean and mean is a fashionable concept adopted by the economic man portrayed by Jensen and Meckling (1994). They wrote, "Lean certainly sounds good = better than fat. But the fact that mean has been made into a virtue is a sad sign of the times" (p. 71).

The simplistic assumption behind the concept is that a lean and mean organization has lower costs, higher productivity, a flatter and more flexible structure, more empowered workers, and happier customers. In pursuit of these benefits attributed to lean and mean organizations, corporate managers started reengineering their organizations following the recipes of management gurus like Hammer and Champy (2009). Besides re-engineering, these recipes included rightsizing, restructuring, job separation, workforce imbalance correction, and downsizing.

Gandolfi (2008) wrote that since the mid-1990s, downsizing (the planned elimination of jobs) had become a leading strategy of choice for a multitude of corporations around the world to immediately reduce costs and increase levels of efficiency, productivity, profitability, and competitiveness. He points out that in surveys of corporations that have downsized, only a few have reported some financial improvements, while the majority has been unable to report improved levels of efficiency, effectiveness, productivity, and profitability. He also points out that downsizing produces considerable human consequences (the socalled side- or aftereffects of downsizing) that affect the entire workforce, survivors, victims, and executors, in a most profound manner.

The author wrote a summary (based on extensive surveys) of the human consequences of downsizing: "Survivors generally find themselves with increased workloads and job responsibilities while frequently receiving few or no resources, training, and support; Victims commonly obtain outplacement services and financial packages when exiting the downsized firms; Survivors suffer from a range of sicknesses during the process of downsizing; Executors suffer from similar effects as victims and survivors" (p. 50)

Mintzberg, Simons, and Basu (2002) highlight that perhaps the worst consequence of this trend of restructuring (or downsizing) organizations has been the breaking of the basic covenant between employer and employee: the implicit pledge of security in return for loyalty. When layoffs occur, employees feel betrayed. The authors write, "These feelings of betrayal in the workforce cannot help productivity in the long run, but productivity does not seem to be measured in the long run these days. Quarterly earnings per share are easier to measure" (p. 72).

Aityan and Gupta (2012) conducted a survey on employee loyalty with U.S. corporations and concluded, "The survey showed that the majority of employees do not feel loyalty from their employer, do not believe that companies take their interests into account, and do not trust or respect their managers, while most managers positively assessed the situation. This disparity needs to be thoroughly addressed by companies in order to improve employee loyalty" ( $p$. 1).

The authors explain that this lack of loyalty is especially worrisome in today's business environment. Corporations depend on their employees more than at any other time in the past. This is particularly true in hi-tech, biotech, finance, and other market segments where employee contribution does not directly depend on the nominal time spent at work.

They point out that employee dedication and employee care of corporate interests are part of employee loyalty. However, employee loyalty cannot be expected without reciprocity. To expect a high level of loyalty from its employees, a corporation is expected to show a similar, or even higher, level of loyalty to them. Most of the time, however, this is not happening in the U.S. corporate environment. Despite being dependent on employee loyalty, U.S. corporations show little or practically no loyalty to their employees. It is typical for a company to lay off employees without warning, taking them by surprise.

The authors explain that most employees in corporate America realize that they can be let go at any time and that management would do their best to hide layoff plans. Even the expectation of losing one's job so suddenly, and in quite an intimidating manner, may be enough to destroy employee loyalty. This is just one example of how corporate America is shooting itself in the foot. There are many other examples of corporations showing very little loyalty toward their employees.

\section{Rising prosperity benefits everyone}

Mintzberg, Simons, and Basu (2002) lament that selfishness has gone beyond the corporate world and permeated the entire society. They argue that the homily of the selfish economy that the rising tide raises all boats is either a wonderful convenient truth or a cynical justification for greed, so that "the winners needn't worry about the losers, because there are no losers" (p. 72).

Saez (2013) demonstrates that prosperity in the U.S. has not benefited everyone. From 1993 to 2012 the average real incomes per family grew by only $17.9 \%$ over this 19-year period (implying an annual growth rate of $.87 \%$ ). However, if one excludes the top $1 \%$, average real incomes of the bottom $99 \%$ grew only by $6.6 \%$ from 1993 to 2012 (implying an annual 
growth rate of $0.34 \%$ ). Top $1 \%$ incomes grew by $86.1 \%$ from 1993 to 2012 (implying a 3.3\% annual growth rate). This implies that the top $1 \%$ incomes captured just over two-thirds of the overall economic growth of real incomes per family over the period $1993=2012$.

Saez (2013) also showed (see Table 1) how the bottom $99 \%$ fared in the income distribution in the period between 1993 and 2012. He distinguishes between five sub-periods: (1) the 1993 to 2000 expansion of the Clinton administrations, (2) the 2000 to 2002 recessions, (3) the 2002 to 2007 expansion of the Bush administrations, (4) the 2007 to 2009 Great Recession, (5) and the 2009 to 2012 Recovery. During both expansions, the incomes of the top $1 \%$ grew extremely quickly by $98.7 \%$ and $61.8 \%$ respectively. However, while the bottom $99 \%$ of incomes grew at a solid pace of $20.3 \%$ from 1993 to 2000 , these incomes grew only $6.8 \%$ from 2002 to 2007 . As a result, in the economic expansion of 2002 to 2007 , the top $1 \%$ captured twothirds of income growth.

Table 1 - Real Income Growth by Groups

\begin{tabular}{|c|c|c|c|c|}
\hline Periods & $\begin{array}{c}\text { Average Income } \\
\text { Real Growth in } \\
\text { \% }\end{array}$ & $\begin{array}{c}\text { Top 1\% Incomes } \\
\text { Real Growth in } \\
\text { \% }\end{array}$ & $\begin{array}{c}\text { Bottom 99\% } \\
\text { Incomes } \\
\text { Real Growth in \% }\end{array}$ & $\begin{array}{c}\text { The fraction of total } \\
\text { growth (or Loss) } \\
\text { captured by top 1\% }\end{array}$ \\
\hline $\begin{array}{c}\text { Full period } \\
\text { 1993 to 2012 }\end{array}$ & 17.9 & 86.1 & 6.6 & 68 \\
\hline $\begin{array}{c}\text { Clinton Expansion } \\
\text { 1993 to 2000 }\end{array}$ & 31.5 & 98.7 & 20.3 & 45 \\
\hline $\begin{array}{c}\text { 2001 Recession } \\
\text { 2000 to 2002 }\end{array}$ & -11.7 & -30.8 & -6.5 & -57 \\
\hline $\begin{array}{c}\text { Bush Expansion } \\
\text { 2002 to 2007 }\end{array}$ & 16.1 & 61.8 & 6.8 & -49 \\
\hline $\begin{array}{c}\text { Great Recession } \\
\text { 2007 to 2009 }\end{array}$ & -17.4 & -36.3 & -11.6 & 95 \\
\hline $\begin{array}{c}\text { Recovery } \\
\text { 2009 to 2012 }\end{array}$ & 6.0 & 31.4 & 0.4 & \\
\hline
\end{tabular}

Source: Saez (2013)

The author points out that the income growth of $20.3 \%$ of the bottom $99 \%$ from 1993 to 2000 and only $6.8 \%$ from 2002 to 2007 may help explain the disconnect between the economic experiences of the public and the solid macroeconomic growth posted by the U.S. economy from 2002 to 2007. Those results may also help explain why the dramatic growth in top incomes during the Clinton administration did not generate much public outcry while there has been a great deal of attention to top incomes in the press and in the public debate since 2005 .

The Occupy Wall Street (OWS) movement that began on September 17, 2011, in Zuccotti Park, located in New York City's Wall Street financial district, was one the most significant protests against social and economic inequality, greed, corruption and the perceived undue influence of corporations on government - particularly from the financial services sector (Pocock, 2011). The OWS slogan, we are the $99 \%$, refers to income inequality and wealth distribution in the U.S. between the wealthiest $1 \%$ and the rest of the population. The protest was suppressed, but it changed public debate, inspiring a generation of activists (Wedes, 2013).

Kopczuk, Saez, and Song (2010) demonstrated that the income composition pattern at the very top had changed considerably over the century, increasing sharply from the 1920s to the present, and especially since the 1970s. Therefore, a significant fraction of the surge in top incomes since 1970 is due to an explosion in top wages and salaries. Indeed, estimates based purely on wages and salaries show that the share of total wages and salaries earned by the top $1 \%$ had jumped from $5.1 \%$ in 1970 to $12.4 \%$ in 2007 . They also point out that top income earners do not derive their incomes from past wealth but are highly paid employees or new entrepreneurs who have not yet accumulated fortunes comparable to those accumulated during the Gilded Age.

The problem is not income inequality. Some inequality is desirable to reward those that work harder, but it becomes a problem when the income gap between the wealthy $1 \%$ of the population and the remaining $99 \%$ reaches the level it has reached in the U.S. Probably, the majority of the highly paid employees mentioned by Kopczuk, Saez, and Song (2010) are members of the management caste associated with what Locke and Spender (2011) called managerialism. Prominent in this caste are CEOs that take advantage of their position to make risky bets with their corporations to gain huge bonuses, and when these bets generate losses, leave with an absurdly generous golden parachute, like the examples shown in Table 2. 
Table 2 - Selected Payouts to Departing CEOs

\begin{tabular}{|c|c|c|c|c|}
\hline CEOs & Corporations & Year & Size of parachute & Were they worth it \\
\hline Robert Nardelli & Home Depot & 2007 & $\begin{array}{l}\$ 210 \mathrm{~m}, \text { incl. } \$ 84 \mathrm{~m} \\
\text { share options. }\end{array}$ & $\begin{array}{l}\text { The share price plunged. } \\
\text { However, the payout } \\
\text { was agreed during good } \\
\text { times. }\end{array}$ \\
\hline Stan O'Neal & Merrill Lynch & 2007 & $\$ 161.5 \mathrm{~m}$ & $\begin{array}{l}\text { Left after huge write- } \\
\text { downs. Bank was sold to } \\
\text { BofA in 2008. }\end{array}$ \\
\hline Charles Prince & Citigroup & 2007 & $\begin{array}{l}\text { Huge write-downs from } \\
\text { subprime mortgages on } \\
\text { his watch. }\end{array}$ \\
\hline Fred Goodwin & RBS & 2008 & $\begin{array}{l}£ 16 \mathrm{~m} \\
\text { pension. Later reduced } \\
\text { by a third. }\end{array}$ & $\begin{array}{l}\text { Oversaw heavy } \\
\text { subprime exposure and } \\
\text { was bailed out by the } \\
\text { government. }\end{array}$ \\
\hline
\end{tabular}

Source: Adapted from The Economist (2010, July 29).

Piff, Stancato, Côté, Mendoza-Denton and Keltner et al. (2012) have a possible explanation for the unethical behavior of so many CEOs, they conducted seven studies using experimental and naturalistic methods that revealed that upper-class individuals behave more unethically than lower-class individuals: In studies 1 and 2, upper-class individuals were more likely to break the law while driving, relative to lowerclass individuals; in follow-up laboratory studies, upper-class individuals were more likely to exhibit unethical decision-making tendencies (study 3), take valued goods from others (study 4), lie in a negotiation (study 5), cheat to increase their chances of winning a prize (study 6), and endorse unethical behavior at work (study 7) than were lower-class individuals. The mediator and moderator data from the studies demonstrated that upper-class individuals' unethical tendencies are accounted for, in part, by their more favorable attitudes toward greed.

\section{CHEATING NO LONGER CARRIES THE STIGMA THAT IT USED TO}

The valorization of occupation in the U. S. industrial society as one of the principal determinants of social status (Niles \& Harris-Bowlsbey, 2013) is a direct consequence of the separation between mental and physical work introduced by Taylor (1998) in the early $20^{\text {th }}$ century. Degen (2011) explains that under this separation, the shop-floor workers (called bluecollar workers) in the mass production systems created by Ford had no career path, except perhaps to become foremen. On the other hand, the mental workers, or professional specialists (called white-collar workers) had the opportunities to climb up the corporate career ladder for high salaries and social status.

The separation of manual work and mental work has caused students in the U.S. to overvalue obtaining an academic degree. This is because it created in the students the belief that an academic degree is the best opportunity for ascension to higher salaries and social status and at the same time distances them from low prestige and low pay manual work. This class perception between mental workers and manual workers is much less accentuated in European countries and Japan, where skilled craftsmen have high prestige and almost the same salary opportunities as academics. The higher prestige of skilled craftsmen in these countries is a possible explanation why they have a much lower income inequality than the U.S.

The consequence of this class perception is that students are predominantly focused on finding a fast track via an academic degree (preferably an MBA from a prestigious business school). They only consider the acquisition of business knowledge important to promote their objective to gain higher salaries and status and do not see the need to make meaning out of their life experience except for making money.

Another problem is that to reach their ambitious goals some future corporate leaders cheat in their student years to get the necessary academic distinction to have the edge over others in the admission to prestigious universities and the recruiting process by a corporation that offers the highest salaries (preferably investment banks and strategy consultants). It is the end justifying the means.

The International Center for Academic Integrity (2013) found that $73 \%$ of all test takers (including prospective graduate students and teachers) agree that most students do cheat at some point. They also found 
cheating no longer carries the stigma that it used to. Grades, rather than education, have become the major focus of many students.

Brown and McInerney (2008) and Jones (2011) explain that surveys of college and university business students over a period of several decades have revealed that high levels of student academic dishonesty exist on American campuses and that these levels are increasing. The authors also point out that an unquestionable alignment exists between academic honesty and workplace ethics. This alignment plus the increase in the dishonest behavior of business students may be one of the explanations for managerialism and the syndrome of managerialism.

\section{ETHICAL PRINCIPLES AND SKILLED ETHICAL REASONING}

To challenge the misconceptions that promoted managerialism and the syndrome of selfishness and the half-truth on which they are built, professors must dominate and orient future leaders on fundamental ethical principles and the requisites of skilled ethical reasoning.

\section{Fundamental ethical principles}

The Cambridge Dictionary of Philosophy states that the word ethics is commonly used interchangeably with morality, but sometimes it is used more narrowly to mean the moral principles of a particular tradition, group or individual (Audi, 1999). The field of ethics (or moral philosophy) involves systematizing, defending, and recommending concepts of right and wrong behavior.

Rawls (2005), as did Kant, argues that persons have the capacity to reason from a universal point of view, which in turn means that they have the particular moral capacity of judging principles from an impartial standpoint. Such a person would choose to regulate a society at the most basic level by what Rawls called the Two Principles of Justice. These two principles determine the distribution of both civil liberties and social and economic goods:

- The first principle states that each person in a society is to have as much basic liberty as possible, as long as everyone is granted the same liberties.

- The second principle states that while social and economic inequalities can be just, they must be available to everyone equally (that is, no one is to be on principle denied access to greater economic advantage) and such inequalities must be to the advantage of everyone.
Rawls (2005) explains that the two principles are related to each other by a specific order. The first principle, distributing civil liberties as widely as possible consistent with equality, is prior to the second principle, which distributes social and economic goods. In other words, we cannot decide to forgo some of our civil liberties in favor of greater economic advantage.

Friend (2004) points out that Rawls's principles imply that economic inequalities are justified only when the least advantaged member of society is nonetheless better off than she would be under alternative arrangements. So, only if a rising tide truly does carry all boats upward can economic inequalities be allowed for in a just society.

\section{Ethical reasoning}

Paul and Elder (2003) explain that the role of ethical reasoning is to highlight acts of two kinds: those which enhance the well-being of others - that warrant praise - and those that harm or diminish the well-being of others - and thus warrant criticism. They point out that developing ethical reasoning abilities is crucial because there is in human nature a strong tendency toward egotism, prejudice, self-justification, and selfdeception. They wrote, "At the root of every unethical act lies some fort and degree of self-delusion. And at the root of every self-delusion lies some flaw in thinking" (p. 6).

The authors warn that ethics is frequently confused with other divergent modes of thought that often lead to a failure to act ethically (while assuming to be acting ethically). To avoid this, it is important to distinguish the fundamental ethical principles from social conventions, religion, and the law. When ethics is confused with these different modes of thinking, it is common for conflicting social values and taboos to be treated as if they were the fundamental ethical principles.

The authors stress that theological beliefs and laws based on social conventions and taboos cannot override the fundamental ethical principles. As they put it, "Thus much should be clear: as long as we continue to confuse these very different domains of thought, we will never have the foundations for creating a just world."

Ethical reasoning, according to Paul and Elder (2008), is simply the application through critical thinking of the fundamental ethical principles to any act, subject, content, or problem that may influence others. The problem according to the authors is that everyone thinks, but much of the thinking is biased, distorted, partial, uninformed, or downright prejudiced. To avoid this type of shoddy thinking, the ability of critical thinking must be cultivated. They explain that critical thinking is that mode of thinking (about any act, subject, content, or problem) in which the thinker improves the quality of his or her thinking by skillfully 
taking charge of the structures inherent in thinking and imposing intellectual standards upon them.

Paul and Elder (2008) explain that the critical thinker raises vital questions and problems, formulating them clearly and precisely; gathers and assesses relevant information, using abstract ideas to interpret it effectively; and comes to well-reasoned conclusions and solutions, testing them against relevant criteria and standards. The critical thinker thinks open-mindedly within alternative systems of thought, recognizing and assessing, as need be, their assumptions, implications, and practical consequences; and communicating effectively with others in figuring out solutions to complex problems.

Paul and Elder $(2003,2008)$ explain that ethical reasoning based on critical thinking is a self-directed, self-disciplined, self-monitored, and self-corrective way of thinking based on the rigorous standard on the fundamental ethical principles and the and mindful command of their use. It entails effective communication and problem-solving abilities and a commitment to overcome our native egocentrism and sociocentrism.

\section{Example of ethical reasoning}

In reality, ethical reasoning based on the fundamental ethical principles is simple. Let's take the case of Chile and the rising discontent of its population with the free market reforms inspired by Milton Friedman (The Economist, 2006). Chile's popular discontent is rooted in the substantial barriers to upward social mobility and extreme protective mechanisms that prevent long-range downward mobility (Torche, 2007). This lack of social mobility is partially due to educational attainments, but also the use of social networks and the direct transmission of wealth.

Gilbert (2011) quoting Blau, Duncan and Tyree (1978) argues that education plays a double role in this social stratification process. On the one hand, educational attainment is the main vehicle for reproduction of socioeconomic status across generations. On the other hand, it creates opportunities for mobility independently from social origins.

In Chile, only the wealthy can afford higher education (Viñas, 2011). This is because of high costs associated with the free market-inspired privatization of higher education. Consequently, the poor will probably continue poor if social justice does not equalize opportunities for educational attainments, as illustrated in Figure 1. The figure also illustrates the difference between just inequality based on individual merit and Chile's unjust inequality based on family wealth.

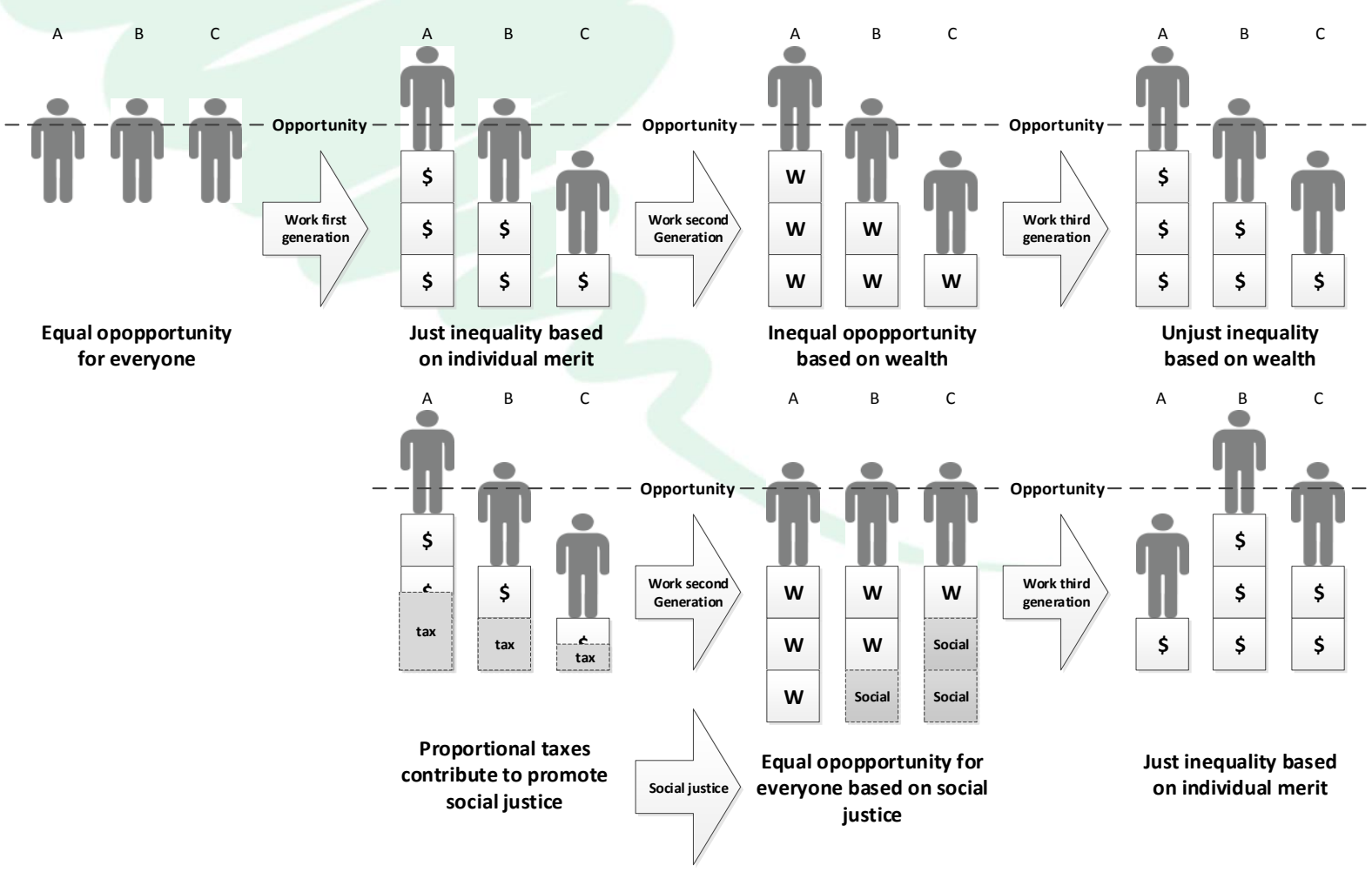

Figure 1 - Equal opportunity for everyone based on social justice. Source: Author 
The explanation why Chile is classified by The Word Bank (2013a) as a high-income country that has a GINI index of $52.1 \%$ and currently ranks as the 19th most unequal country in the world (The World Bank, 2013b) must be attributed to its strict adherence to the free market principles of Milton Friedman and the misconceptions that promoted managerialism and the syndrome of selfishness. Additionally, the Chilean representative democracy has not promoted social justice more aggressively because its political class belongs to or depends financially on the privileged class and so has a vested interest in defending the free market that privileges this class. It was exactly to avoid this perpetuation of a privileged class by the representative democracy that Rousseau (2003) defended the idea that the social contract implied in a strong and direct form of democracy.

\section{HOW PROFESSORS CAN HELP REMEDY THE LACK OF ETHICS IN BUSINESS}

Professors must orient future corporate leaders not only in becoming more productive in their work by acquiring business knowledge; but also, in understanding how to behave and decide properly when confronted with the myriad of ethical dilemmas of the corporate world. To achieve this understanding of what is ethical in our present society, professors must assist them in mastering the necessary ethical reasoning skills so that they learn to apply correctly the fundamental ethical principles and so avoid believing in the misconceptions that promoted managerialism and the syndrome of selfishness.

Another challenge professors face assisting future corporate leaders in their student years in reinforcing their ethical behavior is to explain to the students the importance of finding a meaning in life that is not tied only to higher salaries and social status, and that the option of being a skilled craftsman is as prestigious as being a mental worker. They have to change the selfish beliefs of students that the end (climbing the corporate ladder for higher salaries and status) justifies the means (unethical behavior or plain cheating). Unfortunately, in recent years there have been many examples of senior managers and CEOs acting unethically purely out of self-interest, as in cases like Eron (The Economist, 2002) and the subprime mortgage scandal that triggered the financial crisis in 2007 (Degen, 209).

\section{CONCLUSION}

Professors have the important roles described in this paper in reducing today's lack of ethics in business. For the quest for ethics in business of professors to be successful, it requires that future corporate leaders not only understand how to use ethical reasoning based on the fundamental principles of ethics to their behavior and decisions; it but also requires that they perceive that being ethical is to their advantage in today's world.

Unfortunately, the predominant perception of future corporate leaders (especially in the U.S.) is exactly the opposite. Many believe that being unethical is being smart (being cool) to gain advantages over others. It is the unethical students that cheat that get the better grades and so the first pick of the better jobs, and it is the unethical CEOs that get the big payouts. This belief is reinforced by the fact that unethical CEOs that caused the Great Recession (2007-2009) walked away millionaires and no punishment for the harm they caused to their corporations that had to be bailed out by the government and to millions of homeowners that faced foreclosures (Degen, 2009).

The efforts by professors will have limited effect in reducing the lack of ethics in business if schools, universities, and corporations in the U.S. do not promote aggressively ethical behavior and decision making. Schools and universities must drastically reduce cheating, deconstruct the misconceptions that promote managerialism and the syndrome of selfishness and teach ethical reasoning based on the fundamental ethical principles. Corporations must act ethically in their relations with employees, customers, shareholders, and society as a whole; and introduce ethical behavior and decisions making a key point in the performance evaluations of their employees.

Additionally, corporations have to adopt correct ethical standards and through performance reviews make sure that they are being followed. Unfortunately, many corporations have ethical standards that are vague, tinted with free-market ideas that promote managerialism or are simply not taken seriously.

The negative trends in the U.S. (the growing inequality in income and in access to higher education based on greed, neoliberal selfishness, and the representative democracy that privileges the rich to the detriment of the working class) have to be reversed by reestablishing social justice. This is a formidable endeavor that has to start in schools, colleges, and universities by teaching future generations of citizens and corporate leaders ethical reasoning based on the fundamental ethical principles. Future generations have to understand how to behave and decide properly when confronted with the myriad ethical dilemmas of today's connected and fast-paced world. 


\section{REFERENCES}

Aityan, S. K., \& Gupta, T. K. P. (2012). Challenges of employee loyalty in corporate America. Business and Economics Journal, (55), 1-13.

Audi, R. (1999). The Cambridge dictionary of philosophy (2nd ed.). Cambridge: Cambridge University Press.

Blau, P. M., Duncan, O. D., \& Tyree, A. (1978). The American occupational structure. New York: Free Press. (Original work published 1967)

Brown, B. S., \& McInerney, M. (2008). Changes in academic dishonesty among business students in the United States, 1999-2006. International Journal of Management, 25(4), 621-632.

Business Roundtable. (2012). Principles of corporate governance 2012 [Pamphlet]. Retrieved from http://businessroundtable.org/uploads/studiesreports/downloads/BRT_Principles_of_Corporate_Gov ernance_-2012_Formatted_Final.pdf

Collins, J. C. (2001). Good to great: Why some companies make the leap--and others don't. New York, NY: Harper Business.

Degen, R. J. (2009). Moral hazard and the financial crisis of 2007-9: An explanation for why the subprime mortgage defaults and the housing market collapse produced a financial crisis that was more severe than any previous crashes (with exception of the Great Depression of 1929) (Research Report No. 46).

Retrieved from

http://globadvantage.ipleiria.pt/files/2009/10/working_ paper-46_globadvantage.pdf

Degen, R. J. (2011). Fordism and Taylorism are responsible for the early success and recent decline of the U.S. motor vehicle industry (Technical Report No. 81). Retrieved from

http://globadvantage.ipleiria.pt/files/2011/09/working_ paper-81_globadvantage.pdf

Friedman, M., \& Friedman, R. D. (2002). Capitalism and freedom (40th ed.). Chicago: University of Chicago Press. (Original work published 1962)

Friend, C. (2004). Social contract theory. In Internet Encyclopedia of Philosophy. Retrieved from http://www.iep.utm.edu/soc-cont/

Gandolfi, F. (2008). Reflecting on downsizing: What have managers learned? SAM Advanced Management Journal, (Spring), 46-55.
Ghoshal, S. (2005). Bad management theories are destroying good management practices. Academy of Management Learning \& Education, 4(1), 75-91.

Gilbert, D. L. (2011). The American class structure in an age of growing inequality (8th ed.). Los Angeles: Pine Forge Press.

Hammer, M., Champy, J. (2009). Reengineering the corporation: Manifesto for business revolution. New York: Harper Collins. (Original published in 2001)

International Center for Academic Integrity. (2013). Current cheating statistics. Retrieved November 15, 2013, from International Center for Academic Integrity website:

http://www.academicintegrity.org/icai/integrity-3.php

Jensen, M. C., \& Meckling, M. H. (1976). Theory of the firm: Managerial behavior, agency costs and ownership structure. Journal of Financial Economics, 3(4), 305-360.

Jensen, M. C., \& Meckling, W. H. (1994). The nature of man. Journal of Applied Corporate Finance, 7(2), 419.

Jones, D. L. R. (2011). Academic dishonesty: Are more students cheating? Business Communication Quarterly, 74(2), 141-150.

Khurana, R. (2007). From higher aims to hired hands: The social transformation of American business schools and the unfulfilled promise of management as a profession. Princeton: Princeton University Press.

Kopczuk, W., Saez, E., \& Song, J. (2010). Earning inequality and mobility in the United States: Evidence from social security data since 1937. Quarterly Journal of Economics, 125(1), 91-128.

Locke, R. R., \& Spender, J.-C. (2011). Confronting managerialism: How the business elite and their schools threw our lives out of balance. London: Zed Books.

Mintzberg, H., Simons, R., \& Basu, K. (2002). Beyond selfishness. MIT Sloan Management Review, (Fall), 6774.

Niles, S. G., \& Harris-Bowlsbey, J. (2013). Career development interventions in the 21st century (4th ed.). Boston: Pearson.

Paul, R., \& Elder, L. (2003). Miniature guide to understanding the foundations of ethical reasoning. Dillon Beach, CA: Foundation for Critical Thinking. 
Paul, R., \& Elder, L. (2008). The miniature guide to critical thinking concepts and tools. Dillon Beach, CA: Foundation for Critical Thinking Press.

Piff, P. K., Stancato, D. M., Côté, S., Mendoza-Denton, R., \& Keltner, D. (2012). Higher social class predicts increased unethical behavior. Proceedings of the National Academy of Science of the United States of America, 109(11), 4036-4091.

Pocock, L. (2011). Evaluating the 'Occupy Wall Street' protests - in search of a better world for the $100 \%$. Middle East Journal of Business, 6(4), 6-9.

Rand, A., \& Branden, N. (1970). The virtue of selfishness: A new concept of egoism. New York: Signet/New American Library. (Original work published 1964)

Rawls, J. (2005). A theory of justice. Cambridge, Mass.: Belknap Press. (Original work published 1971)

Rosenzweig, P. (2007). The halo effect. New York, NY: Free Press.

Rousseau, J. J. (2003). On the social contract. Mineola, NY: Dover. (Original work published 1762).

Saez, E. (2013). Striking it richer: The evolution of top incomes in the United States (Updated with 2012 preliminary estimates). Retrieved from University of California, Department of Economics website: http://elsa.berkeley.edu/ saez/saez-UStopincomes2012.pdf

Simpson, B. P. (2009). Wealth and income inequality: An economic and ethical analysis. Journal of Business Ethics, (89), 525-538.
Taylor, F. W. (1998). The principles of scientific management. Mineola, N.Y.: Dover. (Original work published 1911)

The Economist. (2002, January 19). Eron: The real scandal. The Economist. Retrieved from https://www.economist.com/leaders/2002/01/17/thereal-scandal

The Economist. (2006, November 17). An enduring legacy. The Economist. Retrieved from http://www.economist.com/node/8190872

The Economist. (2010, July 29). The wages of failure. The Economist. Retrieved from http://www.economist.com/node/16693567

The World Bank. (2013a). How we classify countries. Retrieved from The World Bank website: http://data.worldbank.org/about/country-classifications

The World Bank. (2013b). GINI index. In The World Bank. Retrieved from The World Bank database.

Torche, F. (2007). Social mobility and education in contemporary Chile (Research Report No. 237). Retrieved from New York University website: https://files.nyu.edu/ft237/public/Torche_Mobility_Ed ucation_Chile.pdf

Viñas, S. (2011). The inequality behind Chile's prosperity. Retrieved from Council on Hemispheric Affairs website: http://www.coha.org/the-inequalitybehind-chiles-prosperity/

Wedes, J. (2013, September 17). Occupy Wall Street, two years on: we're still the $99 \%$. The Guardian. Retrieved from http://www.theguardian.com/commentisfree/2013/sep/ 17/occupy-wall-street-99-percent 